\title{
船舶運航におけるエージェント技術の応用
}

\section{A Study on the Computer-Based Agent to Assist Watch-Keeping Tasks}

広 野 康 平*

\section{Kouhei HIRONO}

\begin{abstract}
It has been pointed out that watch-keeping procedures on a bridge are complex and force the watch officers efforts to choice and align tasks adequately to the environment.

The Computer-Based Agent has capabilities to assist a watch officer on the basis of its own abilities to recognize the situation and to decide the plan. This paper describes an application of agent system for the watch-keeping workflow and the protocol between agent and user. As the result, the author is convinced that the agent system can be applied for the wide range of ship management system.

\section{1. 緒言}

航海当直業務の実態を定量的に検証する目的で ワークフローシミュレーションが実施され、その結 果、航海当直業務の特殊性が以下のように指摘され $た^{(1)}$ 。

○外的状況によって所要作業・動作の好理量、種類、

優先順位が変動する。

○短い時間带内（数分間程度）に複数の作業、動作 を要する状況が突発的に出現する。この複数作

業・動作を要する事象はランダムに発生する。

○ワッチレベルを切り替えて作業を分散し作業の集

中を回避する体制はあるものの、ワッチレベル切

替えの判断は当直者個人の主観に依存している。

ここでいうワッチレベルとは、船橋にお゙ける人員 のフォーメーションであり、当直航海士一名体制、

船長十当直航海士の二名体制、船長十当直航海士十 増員航海士の三名体制など、航行環境の厳しさに応 じて切替えられる。

このように航海当直業務には、船位確認など定期 的な奏施が要求されるもの（定型的業務と呼ぶ）と 状況に合わせて実施されるもの（状洗対応業務と呼 ぶ）が混在しており、業務にあたる船長、当值航海 士は都度々々状況を判断し、状況に合わせて適切に

業務の実行手順を組み立て直すことが求められてい る。これには大きな負担を伴うことになり、往々に して、見逃し、手順の間違い、対応の遅れ、作業の 中断などが起こり得る。航海当直業務全体が非効率 になるだけではなく誤った状況判断により運航の安 全性が阻害される可能性がある。

一般的にコンピュータソフトウェアにおけるエー ジェントとは、外部の状態をセンシングし、人間あ るいは他のエージェントとの対話を行って状況を判 断する等、自律的に自己の行動を制御し、自発的に 外部に対して㗢きかけを行うソフトウェアモジュー ルと定義されている。エージェントはこのような機 能を有することから、一定の条件を満たす場合に、 定められた処理を実行するような定期的・定例的な 業務や監視業務に適しているといわれている。

造船業界では、船舶の設計建造過程にエージェン 卜技術を導入しコンカレントな業務遂行を実現する Active Processの開発 ${ }^{(2)}$ が行われてきた。この過程 において、業務プロセスの表現方法が規定されると ともに、プロセス管理により生産の効率と信頼性を 向上させるフレームワークが提案された。ここで エージェントは造船各部門での標準的手順を提示す るとともに、関連する部門間で相互の進捗を連絡し あい、効率的な業務実施を支援する。あわせて各担
\end{abstract}

* 正会員 株式会社 日本海洋科学（T140-0004 東京都品川区南品川2-3-6） 
当者の作業実績を自動的に記録することにより、造 船業務プロセスの改善活動に客観的デー夕を提供す る。つまりエージェントは業務支援とプロセス管理 を担う基盤的技術と位置付けられている。

航海当直業務は、定型的業務と状況対応業務が混 在しており、当直者の混乱を招来しやすいと指摘し た。一方、エージェントシステムは自律的に状況の 把握、ルールの適用による行動の決定を行えるソフ トウェアモジュールであり、一般的には独立して実 施させる監視業務等に適していると言われている。 そこで、エージェントに定型的業務の実施の促進、 状況対応業務の要否判断を担わせることにより、当 直者の混乱を回避し、航海当直業務遂行の信頼性を 維持できるものと考えた。今回エージェントに分担 させた作業は、見張り、船位測定の定期的害施の促 進、交通環境の変化に応じたワッチレベルの切替え の判断、ならびにプロセス実施の記録である。

先にあげた研究成果を基礎技術として利用し、航 海当直業務を支援するエージェントシステムを構築 した(3)。構築したエージェントシステムへ航海当直 業務プロセスを実装し、シミュレーションにより エージェントシステムの有効性を確認したので報告 する。

\section{2.エージェントの開発経緯}

\section{1 業務プロセスの定義}

エージェントが作業管理を行うためには、エー ジェントが可読な形式で業務プロセスを記述する必 要がある。造船業務支援エージェントの開発過程に おいてプロセスの記述方法が検討された(2)。本研究 では、航海当直業務のプロセス記述について当記述 方法を準用する。

業務とは少なくとも一名以上の担当者の作業に よって成り立つものとし、多くの場合複数の担当者、 すなわち複数の作業の連携により、ある出力をもっ て完遂するものと考之る。担当者は、その作業を実 施する権限と責任をもって担当することになる。一 担当者に割り振られる作業をActivityと呼ぶ。

ある業務遂行のために、少なくとも一つ以上の Activityで構成されるネットワークをWorkflowと 呼ぶ。一つのActivityには一人の担当者が一意に決 定するが、一担当者のActivityは一つとは限らず複 数のActivityを受け持つことも有り得る。

Activityは少なくとも一つ以上のWork Element で構成される。Work Elementとはある出力をする ための一連の処理をグループとしたもので、作業単 位と捉之る。異なるActivityの中に同じWork Ele- mentがそれぞれ構成要素として存在することも有 り得る。Work Elementを構成する一連の処理の 個々をOperation と呼ぶ。Operationは担当者の動作 単位で、あるResourceに対するあるActionの組合せ で定義する。Actionは動詞で表現される担当者の所 作であり、ResourceとはActionの目的・対象である。 例えば、レーダを見るOperationでは、「レーダ」が Resourceとなり、「見る」がActionとなる。

\section{2 エージェントシステムの基本構成}

エージェントシステムの基本構成を図 1 に示す。 このシステム構成は造船業務支援エージェントシス テムにて検討されたものである。本研究では当シス テム構成を準用するものとした。

Enterprise Serverは、エージェントシステム全体 の管理を行う。Enterprise Serverは各エージェント が利用するWorkflowの保管、エージェントの登録 とName Serviceおよびエージェント間通信の記録 を担当する。

User AgentはEnterprise Serverから Workflow をロードして、業務支援を実施する。他のUser Agentとの通信はEnterprise Serverを介して行う。

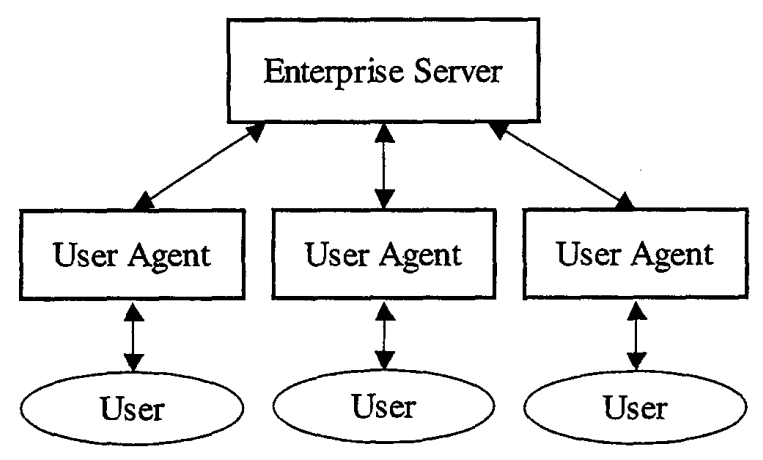

図 1 エージェントシステムの基本構成

\section{3. 航海当直業務支援エージェントの開発}

\section{1 航海当直業務支援エージェントの要件}

船舶運航業務の支援を目的としたエージェントの 機能要件を以下のように整理した。

(1)エージェントは船長以下の各士官職に付随す る。

(2)状況判断を行う。

エージェントは状況判断を行うために、センシン グされたデータの取得あるいは他エージェントへの 問合せを行ってデータならびに情報を収集する。

エージェントは収集したデータ・情報を基に定型 的業務を促進し、かつ状況対応業務の要否を判断す る。本研究では状況対応業務としてワッチレベルの 
切替えに着目した。

(3)ユーザインタフェースを有する。

エージェントはユーザインタフェースを介して、

作業内容を提示するとともに、担当者からの了解 中止等の入力を受け付ける。

(4)作業記録を取る。

エージェントは提示した作業内容と担当者の了 解・中止等の応答結果を時刻を付与して記録する。 その他、状況判断に用いたデー夕、他エージェント との通信内容についても時刻を付与して記録する。

\section{2 航海当直業務支援エージェントの設計・開発} 機能要件を基に航海当直支援エージェントを開発 した(3)。

エージェントは外部世界とのインタフェースを持 ち、センシングされたデータの入力、他エージェン トとのメッセージ交換を行うとともに、ユーザへの メッセージ出力、ユーザからの応答入力を行う。エー ジェント内部には知識ベースがあり、この知識ベー スに現時刻、センサー情報、ユーザ状態などが写像 されるとともに、担当するワークフロー、現作業状 態、ルール、および他エージェントの情報（名前や 通信用ポート番号) が保持される。エージェントは 知識ベースとは別に制御機構を持ち、制御機構が知 識ベースのルールに従ってエージェントの行動を決 定する。これらの機構によってエージェントは周囲 の状況を把握し、他のエージェントと協調しながら、 与えられたプロセスとルールに従ってユーザに作業 内容を提示することが可能となった。

\section{3 航海当直業務プロセスの定義}

造船業務支援エージェントでのプロセス記述方法 に準じて、航海当直作業における業務プロセスを作 成した。エージェントに与えた業務プロセスの具体 的内容を以下に示す。（）内の記述はユーザインタ フェースにて使用する各名称である。

I ワッチレベル 1 のWorkflowとルール

1）当直航海士用エージェント

(1)見張り Activity (LOOK OUT)

a) 目視監視Work Element (Naked Eye) i 他船監視Ope. (Target Search) ii 障害物監視Ope. (Obstacle Search) iii海象監視Ope. (Sea State Check) iv気象監視Ope. (Weather Check)

b) レーダ監視Work Element (RADAR) i 他船監視Ope. (Target Search)

c）衝突危険評価 Work Element（Risk Judgment)

i 方位変化監視Ope. (Bearing Trend
Check)

ii DCPA と TCPA確認 Ope. (DCPA / TCPA Check)

(2)船位測定Activity（POSITION FIX）

a ) 船位取得Work Element (Measure)

i 万位角計測Ope. (Cross Bearing)

ii レーダ距離計測 Ope.（Radar Distance)

iiiGPS計測値取得Ope. (GPS)

iv 天測Ope. (Celestial Observation) $\mathrm{v}$ 位置記入Ope. (Position Plotting)

b) 船位確認Work Element (Confirm)

i コースライン比較Ope. (Comparison with CoLine)

ii 偏位傾向確認Ope. (Deviation Trend Check)

(3)避航操船Activity (COLLISION AVOID)

a）避航ルートの選定Work Element (Select Opportunity Route)

i 航法適用Ope. (Rule Regulation Appling)

ii 危険域接近予測 Ope. (NoGoArea Approach Simu.)

iii他船出会い子測Ope. (Encounter Situation Simu.)

iv避航針路決定Ope. (Avoid Co Decision)

b) 避航操船Work Element (Execute to Avoid)

i 変針号令Ope. (Co Change Order)

ii 自船応答監視Ope. (Own Ship Response)

iii相手船動静監視Ope. (Target Ship Response)

iv他船方位変化監視Ope. (Target Bearing Change)

$\mathrm{v}$ 再接近距離確認Ope. (Most Closest Distance)

vi復針号令Ope. (Co Again Order)

ルール：

見張りActivityの実施を10分を超えない間隔で促 す。

船位測定Activityの実施を15分を超えない間隔で 促す。

2）船長用エージェント 
(1)ワッチレベルの監視Activity

a) ワッチレベルの監視Work Element (Monitor Watch Level)

i ワッチレベル切替えOpe. (Switch Watch Level)

ルール：（ワッチレベル切替えの判断条件として 交通環境を対象とする。)

TCPA $>0$ 、距離 $<10$ マイル、相対方位 $=$ 前方 左 右 $90^{\circ} 、 \mathrm{DCPA}<2$ マイルの船舶が同時に 2 隻以上存 在する場合は、ワッチレベルを“2”とする。

II ワッチレベル2のWorkflow

1）当直航海士用エージェント

ワッチレベル 1 の(1)見張り Activity、(2)船位測 定Activityを担当

ルール：

見張りActivityの実施を 5 分を超えない間隔で促 す。

船位測定Activityの実施を10分を超えない間隔で 促す。

\section{2）船長用エージェント}

(1)避航操船Activity（当直航海士担当から船長 担当に移管)

ルール：なし

\section{4 ユーザインタフェースの開発}

エージェントに付与するユーザインタフェースの 要件は、ユーザに対するエージェントからのメッ セージを適宜表示する出力機能と、ユーザからの了 解・中止等の応答を受け付ける入力機能を持つこと である。ユーザに対するメッセージ表示については、 現作業状況の認識を容易にすることを考慮し、ユ一 ザの担当Activity、Work Element、Operationを階 層的に表示するものとした。図 2 にActivity、Work Element、Operationの表示例を示す。

エージェント・ユーザインタフェース・ユーザ間 のやりとりの例を図 3 に示す。エージェントはWor. kflow、すなわちActivity、Work Element、Operationの階層構造をノードの連接として管理してい る。エージェントが状況判断に基づいてユーザにあ る作業実施を促す場合、ユーザインタフェースに対 して、該当するノード番号 (Node) とノードに対す る指示 (ORDER)、ユーザへのメッセージ文 (Mes-

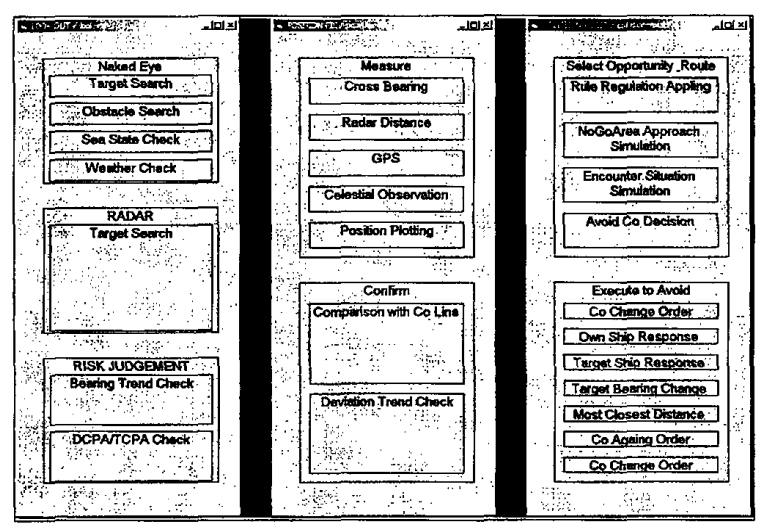

図 2 ユーザインタフェース画面の例（見張り Activity、船位測定Activity、避航操船 Activity)

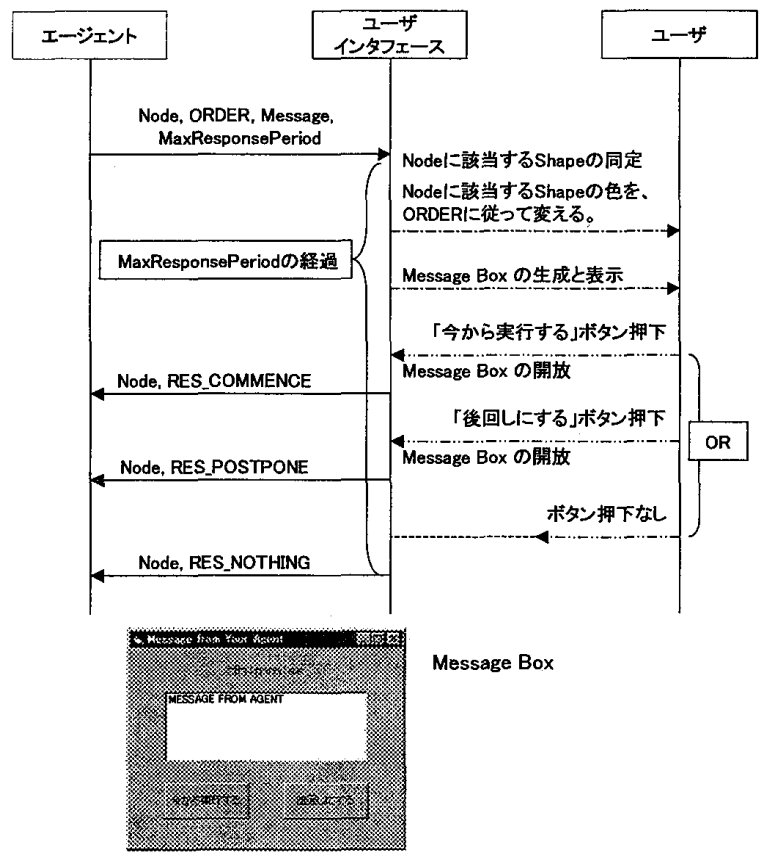

困 3 エージェント・ユーザインタフェース・ ユーザ間での状態推移の例

sage)、ユーザ応答までの許容時間 (Max Response Period）を送るものとした。ユーザインタフェース は、指定されたノード番号から該当するShape(表示 用のオブジェクト)を同定し、ORDERに従って色を 変化させ、ユ一ザの識別を容易にする。あわせてメッ セージボックスを生成・表示させる。メッセージボッ クスにはエージェントからのメッセージ文を表示 し、ユーザによる応答ボタンを配置させる。罒 3 に 示した例では応答ボタンは「今から実行する」と「後 回しにする」である。

ユーザインタフェースはユーザによるボタンの押 下によってユーザの応答を検知し、ボタンに対応す る内容 (RESPONSE) をエージェントに返す（この 例では、RES-COMMENCE \&しくはRES- 


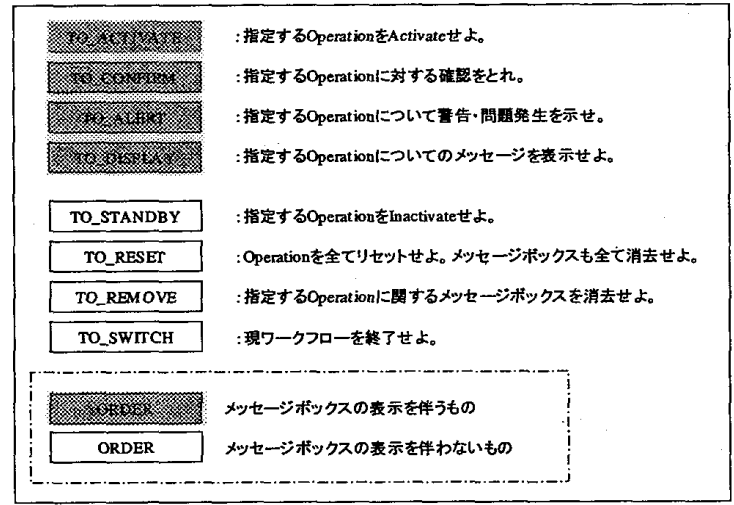

困 4 エージェントからのユーザインタフェース に対するORDER

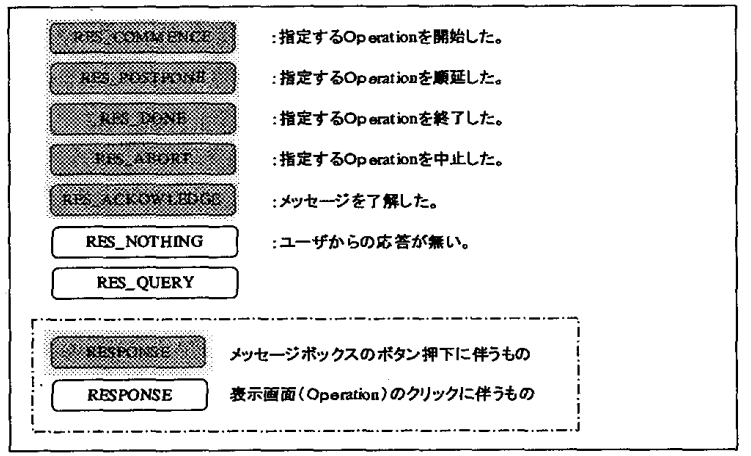

図 5 ユーザインタフェースからのエージェント に対するRESPONSE

POSTPONE)。先に指定されたユーザ応答までの許 容時間 (MaxResponsePeriod) を経過してもユーザ のボタン押下が無い場合は「応答なし」(RESNOTHING) を返す。ユーザインタフェースから エージェントにユーザの応答を返す際には該当する ノード番号を付すこととした。これによりエージェ ントは、ノードに対するORDERとRESPONSEを一 意に識別することができるので、同時に複数の作業 指示・応答受付を管理できる。

ユーザに対するメッセージ出力とユーザ応答入力 について、状態推移を種々考慮し、図 4 および図 5 に示すORDERおよびRESPONSEを規定した。

\section{5 機能検証}

\section{5 .1 シミュレーションの実施}

開発したエージェントシステムの機能を検証する ためシミュレーションを実施した。検証シミュレー ションの目的は、エージェントシステムの基本要件 としてあげた、(1)定型的業務の遂行についての促進、 (2)ワッチレベルの切替えに関する判断、(3)プロセス 実行の記録についての各機能の確認である。

航海当直業務の特殊性として、定型的業務と状況 対応業務の混在を指摘した。検証シミュレーション
では突発的に発生する事象として他船との出会いを 想定した。エージェントに対してこの出会い状況を 定量的に評価して、目的の(2)ワッチレベル切替えの 判断を行わせるものとした。エージェントは船長の 登橋を促し、当面航海士のActivityであった「避航操 船」を船長に移管させることとした。この結果、当 直航海士と船長と間で業務の分担が図られ、状況に 対応した当直体制となることを確認するものとし た。

\section{5 .2 シミュレーション環境}

シミュレーションのためのシステム構成を図 6 に 示す。

Sensor Data Serverは、GPS装置、レーダ装置を 代替する(4)。自船および他船の位置、針路、速力を計 算し、ARPA情報を生成する。Resource Agent (レー ダエージェント) はレーダ装置監視に専従するエー ジェントとした。レーダエージェントはEnterprise Serverを経由して送られてくる監視状態の問合せ に対して回答する。Manager Agentは船長付きの エージェント（以下、船長エージェント）であり、 船長用のWorkflowをEnterprise Serverからロード して、船長の業務を支援する。ここではレーダエ一 ジェントに対して周囲の状況を適宜問い合わせ、回 答状況からワッチレベルの切替えを判断する。User Agentは当直航海士付きのエージェント (以下、航海 士エージェント) である。船長エージェントと同様 に航海士ェージェントは当直航海士のWorkflowを Enterprise Serverからロードし、Workflowに従っ て実行すべきOperationを適宜提示し、作業遂行を 支援する。

\section{5 .3 検証シナリオと検証結果}

シミュレーション海域は伊豆大島東方で、自船は 洲崎沖変針点向け航行中とした。このとき検証の便 宜上ワッチレベルを 1 (当值航海士一名体制) とし てシミュレーションを開始した。ワッチレベル1での 当值航海士のActivityは「胃張り」Activity、「船位 測定」Activity、ならびに「避航操船」Activityの三

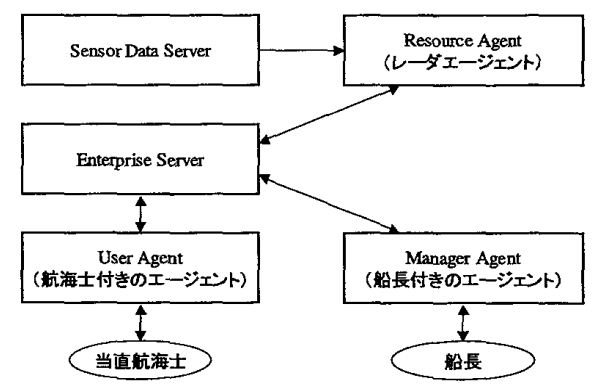

困 6 機能検証のためのシステム構成 
つである（図 2 参照）。航海士エージェントが適宜 Workflowに従って目視による監視、レーダによる 監視、ならびに船位測定のOperationを促し、当直航 海士の作業遂行を支援する状況を確認した（図 7)。 一方、船長エージェントはレーダエージェントに対 して他船の監視状況を問合わせを適宜実施した。 ワッチレベル1であるので、船長は船橋にはいない設 定であるが、船長エージェントは船内LANを通じて 船橋のレーダエージェントと通信できている。船長 エージェントは、レーダエージェントの回答から ワッチレベルを切替える状況であると判断し、船長 にその旨を通知した（図 8)。今回のワッチレべル切 替えの条件は「TCPAが正で、DCPAが1 マイル以下 となる船舶が、同時に、10マイル以内に2隻以上存在 する場合」とした。船長エージェントは、船長の了 解の後、航海士エージェントに対してワッチレベル の切替えを指示し、航海士エージェントは指示に従 い現Workflowをワッチレベル2（船長十当值航海 士二名体制) 用のWorkflowに切替えた。ワッチレベ ル2における当直航海士のActivityは「見張り」と「船

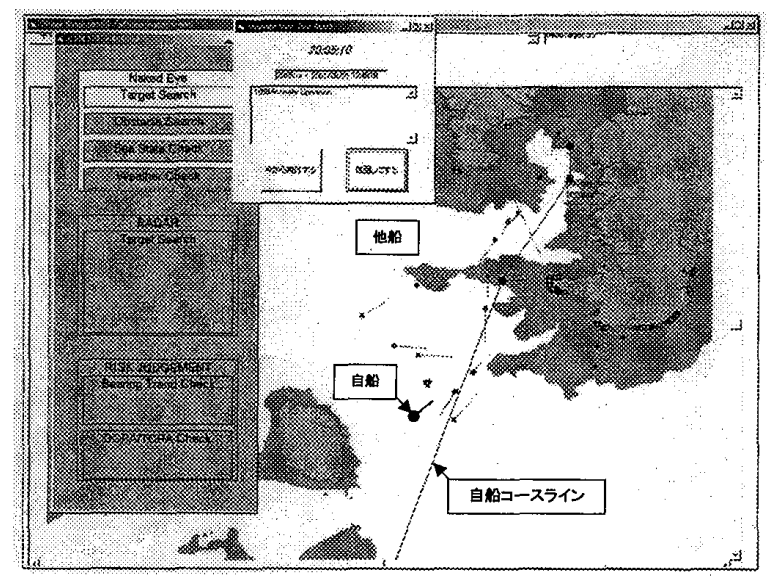

図 7 航海士エージェントによる作業内容 （目視による監視Operation）の提示

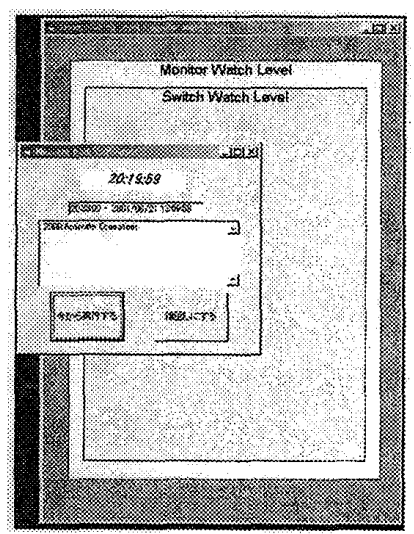

図 8 船長エージェントによるワッチ レベル切替之の確認要求

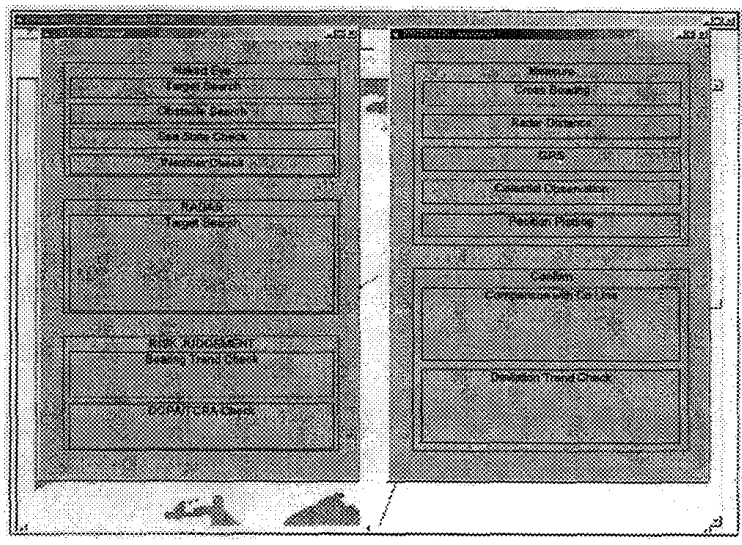

図 9 ワッチレベル2における当直航海士の Activity（「見張り」と「船位測定」に 限定された）

位測定」の二つに限定され、船長が「避航操船」 Activityを担当することになる。航海士エージェン トはワッチレベル2に切り替わった後もワッチレベ ル1のときと同様に当直航海士の支援を継続した(図 $9)$ 。

\section{4. 結 論}

航海当直業務の特殊性として、定型的業務と状況 対応業務が混在し、当直者の混乱を招きやすいこと を指摘した。すなわち、定型的業務の実施過程に状 況対応業務が突発的に割り込むことが多く、それま での業務の中断や実施すべき業務のスキップが発生 し、作業の誤り延いては航海当直自体の破綻をきた す可能性がある。現害的にはワッチレベルと称する 船橋でのフォーメーションがあり、状況対応業務が 頻繁に発生し当直者一人では能力的に対処できない 状況になった場合にはレベルを切替えて、すなわち 複数人員に業務を分担させて、定型的業務と状況对 応業務を分離する。業務は担当者により専属的に実 施され、航海当直としてのパフォーマンスの維持・ 向上が図られる。

しかしながら、ワッチレベルの切替之判断は現状 では当直者の主観に依存しており、適切な判断が下 せない可能性が残存している。

そこで、エージェントシステムに航海当直のプロ 七ス管理として、定型的業務実施の促進、定量的な 状況判断、プロセス寒行の記録を行わせることとし た。

エージェントシステムを開発し、あわせて航海当 直業務のプロセスとルールを記述し、これらをエ一 ジェントシステムに実装した。

検証シミュレーションにおいて、見張りの実施、 
船位測定の笑施等の定型的業務について航海士用 エージェントによる促進を確認した。また、船長用 エージェントに交通環境の監視を連続的に行わせ、 ルールに則ってワッチレベル切替えの判断ができる ことを確認した。両エージェントは、当直航海士な らびに船長に促した作業について、時刻と応答内容 を記録できることを確認した。

これらのことから、定型的業務と状況対応業務の 必要性が同時に発生し、当直者が状況対応業務にあ たったとしても、エージェントは定型的業務実施の 必要性を当直者に示すことができ、その時点におい て当直者が実施することはできなくとも、当值者の 注意を留めおくことになり、当業務が笎全にスキッ プされてしまうこと防ぐ。また、エージェントはセ ンシングしたデータから数值的に航行状況を判断 し、その時々においてなすべき作業を判断すること から、航海当直業務の実施について一定の基準を与 えることができると考えられる。エージェントの支 援によって業務の実施が担保され、また、客観的な 状況の判断に基づいて実施すべき業務が選択される ことになるので、航海当直業務の遂行についての信 頼性が向上し、延いては航行の安全性が維持される ものと期待できる。

本研究では、東京湾入り口付近において、エージエ ントが、定期的な見張り、船位測定の実施を促進し、 また交通環境の変化に対応してワッチレベルの切替 えを判断するルールについて検証した。航海当直業 務としては、さらに輻輳している海域での航行、あ るいは狭水道域での航行など種々の状況に応じたも のがあり、それぞれについて業務プロセスのオプ ションが存在すると思われる。通常、輻輳海域や狭 水道を航行する場合には、ワッチレベルを“2”、も しくは “3”として複数員の役割分担の中で航海当直 業務が遂行される。今後の課題として、このような 航行状況の違いごとに船長以下、各航海士の業務プ ロセスとエージェントに持たせるルールを設定し、 各員の役割分担、つまり連携プレーに応じたエー ジェントによる業務促進、状況判断についての検証 を行い、現実的、かつ実用的なシステムとしての要 件を特定、対応していく必要があると考える。

また、現時点でのエージェントは一方的に業務笑 施を提示するのみである。ユーザとしては業務遂行 にあたり、その業務の内容や今後のスケジュールを 確認する要望を持つはずであるので、エージェント は業務実施を促進するだけではなく、これらのユー ザからの要求に対応する機能を持たせる必要がある と考える。
いまのところ、エージェントとユーザとのやりと りは画面操作によっているが、実際の船橋において 画面操作を強いることは現実的ではないと考えてい る。双方向で音声によるやりとりの実現を課題と考 える。

将来的には船舶運航管理会社はこれらのエージェ ントによる業務実施の記録を解析することにより、 航海当直業務での作業の着手・終了の事実に加え、 作業の集中具合を確認することが可能となる。さら に踏み込んだ解析により、船員の技量不足、与えた 業務プロセスと現場との齕嚙、あるいはエージェン トの判断が実際に則していないなど、問題点の特定 が可能になり、問題䇢所を特定することにより、教 育・訓練の実施、作業分担の改編、エージェントの 持つ状況判断ルールの改定など次の手立てをとるこ とが可能となる。結果、船舶運航管理会社は現在の 航海当直業務の信頼性を保障するだけではなく、現 業務に内包される問題点を特定することにより改善 を容易にし、業務の效率化、信頼性延いては安全性 の向上につなげることが可能となると考える。

\section{参 考 文 献}

（1）社団法人 日本造船研究協会, SR238新しいフ リートサポートシステムの研究成果報告書, 平 成11年 3 月.

（2）財団法人 シップ・アンド・オーシャン財団， 知識共有を基盤とした高度造船CIMの開発研 究報告書, 平成11年度.

（3）安藤英幸・広野康平・大和裕幸，マルチエージェ ントによるチーム航行支援, 第10回マルチ・エー ジェントと協調計算ワークショップ (MACC2001) に投稿中.

（4）社団法人日本造船研究協会, 第240研究部会/ 新しいフリートサポートシステムの開発平成 12 年度報告書, 平成 13 年 3 月。

\section{質 疑 応 答}

林 尚吾 (東京商船大学)：「エージェント技術」に ついて補足説明をお願いします。

広野康平：多くのコンピュータソフトは、利用者の 作業の過程内で、利用者の都合により起動され、 利用され、終了されています。一方エージェント は、原則として利用者の作業とは別個に、バック グラウンドで、独立して作動しています。予め設 定された条件になった場合、これもエージェント が独自に判断するわけですが、定められた作業を 実行します。エージェントとは、コンピュータの 
作業をユーザが明示的にON・OFFするのではな く、作業の実行を「陉せ」することのできるり フトウェアであると考えることができます。例え ば、電子メールソフトには、ある送り主から来た メールは、指定したフォルダに保管するといった 機能を持つものがあります。この機能は、ユーザ の指示を受けなくても、ユーザの「代理」でメー ル着信を監視し、送り主を判別し、指定フォルダ へ転送します。このような機能はエージェントと 捉えることができます。エージェントがエージェ ントとして機能するためには、外部からのデー夕 入力、データの解釈、ルールの適用、ルールの管 理、ルールに従った行動の出力といったサブ機能 が必要になります。サブ機能を実現する通信・情 報処理技術とこれらの技術を統合・運用する技術 をエージェント技術と呼んで良いかと思います。

林 尚吾：「エージェント」とは、一般には「代理 店」「代行業者」という意味ですが、『本社からの 指示を受けて自律的に行動する代理店』というよ うに考えて良いですか。

広野康平：この場合、本社からの指示とは、いわゆ るSMSマニュアルに相当するものと、その航海に おける航海計画（パッセージプラン）と捉えます が、「代理店」の言葉をそのまま適用してしまうと、 航海士に成り代わって当直するものとの印象が強 くなってしまいます。どちらかというと、本社の 指示を間違いなく実行するため適宜注意喚起をし てくれる、ちょっと気の利いた「電子システム手 帳」と申し上げた方がイメージは近いかと思いま す。
小川征克(独立行政法人 航海訓練所)：本研究の今 後の方向として、(1)エージェントの役割が十分な らば「当直航海士」という人間は不要、(2)エージェ ントを十分に活用したとしてもやはり「当直航海 士」は必要、の二つを考之た場合、どちらの方向 をイメージされていますか。

広野康平：人間の「当直航海士」は必要と考えてい ます。航海当直機能を完全にコンピュー夕に置き 換えるか、否か、との見方ではなく、人間の弱い ところをどのようにコンピュータによって補って いけるのかとの見方をしています。コンピュータ は機能不全でない限り与えられた仕事は確実に実 行しますから、人間が犯しがちなうっかりミスや、 見落としなどの発生を未然に防止する役目を負わ せ、また周囲の状況を数值的に示すことによって 人間の判断から曖昧さを排除させることができる と思います。また、一度記憶した内容を忘れるこ とがありませんので、作業実績などの記録管理に 適していると考えます。

エージェントが業務プロセスを仲介し、箺際に 行われた作業の実績を記録することにより、事後 の解析を通じて業務プロセスの改善を継続的に実 施することができるようになります。この改善を 繰り返すことにより、より現実的な業務プロセス が構築できるようになると思います。改善を繰り 返した業務プロセスは、ある意味で船員のノウハ ウの蓄積であり、これをエージェントを介して各 船で共有することができますので、船社あるいは 管理会社としての高度なレベルでの輸送品質の均 質化が図れると考えます。 